Teaching
Methods

\section{Development and Implementation of a Nonmajors Horticultural Survey Class}

\author{
Jennifer Campbell Bradley,
}

Dennis McConnell, ${ }^{2}$

Michael Kane, ${ }^{2}$ and

Grady Miller ${ }^{3}$

\section{Additional index words. teaching, gardening, plants, learning, course summary}

Summary. Attracting new students into traditional agriculture programs has become increasingly difficult. Offering a survey course as a means for introducing students to agriculture is a concept with popular appeal. As a recruiting effort, and as a method of introducing students to horticulture, the Environmental Horticulture Department at the University of Florida, Gainesville, designed a one-credit course for nonmajors. The course was structured to provide a broad overview of horticulture, emphasizing plant use to enhance interior and exterior environments. The intent was to develop a course somewhat similar to an entry-

\footnotetext{
$\overline{\text { Department of Environmental Horticulture, Univer- }}$ sity of Florida, Gainesville, FL 32611-0670.

Florida Agricultural Experiment Station journal series.

${ }^{1}$ Assistant professor.

${ }^{2}$ Professor.

${ }^{3}$ Associate professor.
}

level course for majors, but with each lecture devoted to a single, selfcontained topic. When feasible, hands-on activities were incorporated within the classroom presentation. The course ORH 1030-Plants, Gardens, and You was offered for the first time in Summer 1997. It is now offered every semester. The course has one faculty assigned each semester and various other faculty members, including teaching, research, and extension specialists, participate as guest lecturers. Methods to improve the course are discussed by the faculty presenters and the course coordinator each term. Student response to ORH 1030 has been favorable, ratings are high and enrollment in the course has continued to rise from 30 to our current cap of 100. As a means of ensuring that we are meeting the needs of our students and to aid in targeting potential students, a survey was administered in Spring 2000. Students enrolled in the course were surveyed at the beginning and the end of the semester to gain insight into student demographics, horticulture background and experience, reasons for enrollment in the class, and overall interest in the course.

A ttracting new students into traditional agriculture pro grams has become increasingly difficult (Dalmasso, 1990, Dyer et al., 1999;). In the new era of departmental reductions, horticulture programs are experiencing reduced student numbers (Barrett, 2000), despite growing career opportunities for college graduates. Most university agricultural programs, especially environmental horticulture programs, do not have enough graduating students to meet industry demand (D.B. McConnell, personal communication). Nonmajors may not be attracted to agriculture courses be- cause they have an image of agriculture as an old-fashioned science and may associate agriculture with pictures of horse drawn plows (Handelsman, 1992; Kesler, 2000). Student surveys show that an awareness of potential career opportunities is necessary for students to consider any agricultural academic program area as a major (Donnermeyer and Kerps, 1994).

Kesler (1997a) reported that the overall rating for an animal science course for nonmajors at University of Illinois was very high $(4.85 \pm 0.06$ with $5=$ exceptionally high) when the enrolled students were surveyed. In their class, $86 \%$ of the students were majors in the College of Liberal Arts and Sciences, illustrating the impact this type of course can have on nonagriculture majors. Most of the students $(86 \%)$ in their class said they would consider taking another animal science course.

Some of the most controversial issues in our society involve agriculture (e.g., genetic engineering, environmental pollution, pesticide use). Generally, Americans have low levels of awareness and inaccurate perceptions about agriculture and its impact upon society and the environment (Terry and Lawver, 1995). A course designed for nonmajors emphasizing the use of plants that students encounter on a daily basis could reduce misconceptions about horticultural production and improve agriculture literacy among people educated in curriculums not associated with agriculture or the sciences.

As a recruiting effort, and as a method of introducing students to horticulture, our department began investigating the possibilities of offering a new course for nonmajors. Such a course was envisioned to provide a broad understanding of horticulture, including floriculture, landscape management, nursery production, and turfgrass science. The course would be similar to an entry-level course for nonmajors, but designed to emphasize plants used to enhance exterior and interior environments and to incorporate hands-on activities as part of the lecture presentation. Additional goals of this course were to introduce students to current technology in a nonthreatening manner and to stimulate their curiosity and excitement within the field of horticulture. The intent was to enhance the students' 
opinion of the horticulture discipline, stimulate them to enroll in additional horticulture courses, and consider environmental horticulture as a potential career.

After considering the above stated goals, the Environmental Horticulture Department at the University of Florida, Gainesville developed the survey course ORH 1030-Plants, Gardens, and You for nonmajors. Each lecture was self-contained, devoted to a different area of horticulture, and presented by a guest speaker with expertise in the topic covered. Students were exposed to a variety of subjects including arboriculture, biotechnology, floral design, home lawn care, how to select healthy landscape plants, growing indoor plants, landscape design, and sports-turf. Previous reports indicated that courses with a broad range of appeal designed for nonmajors can attract students from all ranks and colleges represented at an university and increase enrollment in the academic program emphasized by the course (Dalmasso, 1990). Consequently, the concept and format of this course received broad support from all faculty members in our department.

While the development of a new course can be time consuming, we found this course to be even more challenging. This challenge could be attributed to limited information available on methods for constructing a survey course consisting of independent self-contained topics and, when feasible, incorporating hands-on activities in a lecture hall. However, for us, the importance of such a new curriculum venture was undeniable. As the course outline developed, the additional challenge of existing teaching loads became apparent. Since most faculty already had full teaching loads, and we wanted to give students a broad overview of horticulture, it was decided that one faculty member would coordinate the class while various faculty members, including teaching, research, and extension specialists, would contribute guest lectures throughout the semester. Further, it was recommended that the person coordinating the course vary from semester to semester. This system worked-taking the burden away from one professor alone, while at the same time allowing the expertise of departmental professors to be used to the fullest extent as faculty volunteered for topics within their expertise. The course coordinator handled all scheduling for the speakers, graded all student notebooks and papers and assigned final grades. Additionally, the coordinator gave at least one lecture, attended all class meetings, introduced all speakers, and recorded attendance. Limited departmental resources precluded the assignment of any teaching assistants to the course.

Courses must be marketed if one is to achieve enrollment gains in a university environment where many courses compete for student enrollment. The first time the course was offered, personal letters were sent to each entering freshman for that summer semester. Since the course's inception in 1997, it has been taught 12 times. The second and third time the course was offered, flyers were posted around campus in places where freshmen typically have classes. Since the initial first few course offerings, student awareness of this one credit course on plant use has been maintained via word of mouth.

Originally, ORH 1030 was only offered during the summer and spring semesters, but increased student demand and interest has led to the course being offered every semester. The 1credit class meets once a week for a 50 min period during the regular semesters and twice a week during the eight week summer semester. In consideration of speaker availability and schedules, topics and dates vary slightly each semester. A generalized list of topics includes course introduction and overview, annuals and perennials, arboriculture, bonsai, butterfly gardens, the edible garden, floral design, floriculture, flowering bulbs, genetic engineering, interior plants, internet resources, landscape design, plant production, plant propagation, plant selection, and turfgrass.

Initially, grades and grading policies were difficult to determine, as this class had never been taught before. Currently, the students are required to create a course notebook that is an accumulation of all their notes and the class handouts. No exams are given and the course grade is based primarily on class attendance, the student's notebook, a short paper discussing a horticultural topic of their choice, and short reports on exercises started in class but evaluated by the students at their residences. The educational process in this course focuses on nonformal education, imparts an awareness of the multiplicity of ways that plants influence students' lives and minimizes the elements that often occupy formal education. Kesler (1997b) designed a course using a similar format for teaching a nonmajors animal science course. The absence of tests and other traditional psychological stressful criteria to achieve an A made the course an ideal balance compared to the academic requirements of most other courses in a student's schedule. Kesler (1997b) required a final examination (equally divided into take-home and in-class sections), and a short oral report in addition to weekly discussions and a notebook. The emphasis was put on discussion in class rather than on note taking.

Overall, ORH 1030 has been judged to be a success. Our department plans to continue to offer this course each semester. For other departments and institutions interested in pursuing a nonmajors survey course or developing a new course with multiple instructors these suggestions may help: 1) make the class interesting, 2) survey the students to gain their perspective, and 3 ) provide for a course wrap-up session where participating instructors discuss methods to improve the next semester's class.

Make the class interesting. Part of the success of making this class work is that word of mouth has and continues to attract students to this class. We knew that the format would have to be interesting. The class is designed for and directed to nonhorticulture majors, thus, students taking the class vary considerably. We have students from all colleges including accounting, agriculture, business, education, engineering, fine arts, journalism, liberal arts, and natural resources that take this course. Although the course is an elective and meets no other university requirement student numbers have climbed each semester the course was offered until our selfimposed limit of 100 students was reached. Obviously, word of mouth, did promote student interest. The first semester the course was offered, it had 30 students. The last time it was offered, enrollment was at 101 .

One aspect of developing an interesting class is to incorporate handson activities within the lecture presentation. Throughout the semester, in- 
Table 1. Demographicinformation of students participating in ORH 1030 Plants, Gardens, and You (N = 95).

\begin{tabular}{|c|c|}
\hline $\begin{array}{l}\text { Demographic } \\
\text { variable }\end{array}$ & $\begin{array}{l}\text { Proportion of } \\
\text { students }(\%)^{\mathrm{Z}}\end{array}$ \\
\hline \multicolumn{2}{|l|}{ Gender } \\
\hline Male & 41.9 \\
\hline Female & 58.1 \\
\hline \multicolumn{2}{|l|}{ Age } \\
\hline $17-19$ & 20.4 \\
\hline $20-22$ & 74.2 \\
\hline $23-25$ & 4.3 \\
\hline$\geq 26$ & 1.1 \\
\hline \multicolumn{2}{|l|}{ Race } \\
\hline African American & 5.4 \\
\hline Asian American & 9.8 \\
\hline Caribbean & 3.3 \\
\hline Caucasian & 67.5 \\
\hline Hispanic & 7.6 \\
\hline Other & 6.4 \\
\hline \multicolumn{2}{|l|}{ Classification } \\
\hline Freshman & 6.4 \\
\hline Sophomore & 15.1 \\
\hline Junior & 19.4 \\
\hline Senior & 58.1 \\
\hline \multicolumn{2}{|l|}{ Grade point average } \\
\hline $\mathrm{A}$ & 35.5 \\
\hline $\mathrm{B}$ & 55.9 \\
\hline $\mathrm{C}$ & 7.5 \\
\hline $\mathrm{D}$ & 1.1 \\
\hline
\end{tabular}

${ }^{2}$ Valid percent reported (rounding may yield totals $<100 \%$ ).

Table 2. Colleges represented by students participating in ORH 1030 Plants, Gardens, and $\mathrm{You}(\mathrm{N}=95)$.

\begin{tabular}{lc}
$\begin{array}{l}\text { Colleges } \\
\text { represented }\end{array}$ & $\begin{array}{c}\text { Proportiono } \\
\text { students(\%) }\end{array}$ \\
\hline Accounting & 3.2 \\
Agriculture & 13.7 \\
Business & 23.2 \\
Education & 1.1 \\
Engineering & 8.4 \\
Fine Arts & 2.1 \\
Journalism & 8.4 \\
Liberal Arts & 34.7 \\
Natural Resources & 2.1 \\
Undecided & 3.1 \\
\hline
\end{tabular}

$\overline{{ }^{2}}$ Valid percent reported (rounding may yield totals $<100 \%)$.

structors strive to make his or her lecture period as interactive as possible. Examples include floral design; students create floral arrangements with instructor guidance, and the micropropagation lecture where every student in the class propagates their own test-tube plant. Each of the guest lecturers is encouraged to promote interactive learning. During each semester, the topics discussed included information of interest to any student taking the course. A handout that summarizes each speaker's presentation is prepared and distributed so students can focus on the discussion and take notes in a logical, organized manner. Whether the student chooses horticulture as a career or not, the information presented in class will be useful for any future gardening or plant care. In addition to hands-on activities, students are provided various gardening plants and related materials to take home. To cover the additional expenses for these supplemental materials, a \$10 laboratory fee is accessed for this course. This format provides the flexibility needed to promote interest and involvement by the students.

Student survey. In Spring 2000, the students taking the class were surveyed to determine their opinion, attitude, and knowledge at the beginning of the course and on the last day of class using the same survey. This survey helped to collect information about the students who chose to take the class and their attitudes towards the College of Agricultural and Life Sciences, and horticulture sciences. Specific items that were included in the survey included: biographical information, student's college, the student's first exposure to horticulture, the reason for enrolling in the class, and overall course satisfaction.

Males encompassed $42 \%$ and females $58 \%$ of the students enrolled in the course (Table 1), while overall University of Florida (UF) enrollment is $51.5 \%$ male and $48.5 \%$ female (UF, 2000). Caucasian students were, by far, the majority of students participating in the class. The largest percentage of students was ages 20 to 22 . One faculty concern was the high number of seniors enrolled in the class, $58 \%$. If this class is to serve as a recruiting tool, the high percentage of seniors greatly limits its effectiveness. At UF, seniors are allowed to register first and the class has a disproportionate number of seniors. One thought is to limit enrollment to freshmen and sophomores.

The information obtained from students about their colleges indicates that our population is varied (Table 2). Students from Business Administration $(23.2 \%)$ and Liberal Arts (34.7\%) were the two largest student groups. These are also the two largest colleges at UF; Liberal Arts comprises 27\% and Business Administration 13.8\% of the student population (UF, 2000). The College of Agricultural and Life Sciences was represented by $13.7 \%$ of the students in our class although they represent $8.0 \%$ of the UF student body. These findings are encouraging as they indicate we are reaching a broad spectrum of students within the university.

We also wanted to determine students' first exposure to horticulture. Not surprisingly, most students (55\%) had experience with horticulture as a child, before the age of 8 (Table 3 ). However, this finding proved interesting in that $20 \%$ of the students indicated that they had not had exposure prior to taking this course.

The decision to enroll in this course provided useful information. The largest group (45\%) was students interested in growing plants and learning more about gardening in general (Table 4). An unrelated but strong factor in students' decision to enroll in ORH 1030 was their need to find a one-credit course $(41 \%)$ to fulfill their requirements for graduation.

We wanted to determine overall course satisfaction by asking students to respond on a Likert-type scale (Likert, 1967), where 1 = lowest course satisfaction and $5=$ highest course satisfaction. Findings indicated that

Table 3. Students participating in ORH 1030-Plants, Gardens, and You and their first exposure to horticulture $(\mathbf{N}$ =95).

\begin{tabular}{lc}
$\begin{array}{l}\text { First } \\
\text { exposure }\end{array}$ & $\begin{array}{c}\text { Proportio } \\
\text { students(\%) }\end{array}$ \\
\hline Before the age of 8 & 54.7 \\
Between ages 9-16 & 17.9 \\
After the age of 17 & 7.4 \\
This course was first exposure & 20
\end{tabular}

${ }^{2}$ Valid percent reported (rounding may yield totals $<100 \%$ ).

Table 4. Students participating in $\mathrm{ORH}$ 1030-Plants, Gardens, and You and their decision to enroll in the course $(\mathbf{N}$ = 95).

\begin{tabular}{|c|c|}
\hline $\begin{array}{l}\text { Decision } \\
\text { toenroll }\end{array}$ & $\begin{array}{l}\text { Proportion of } \\
\text { students }(\%)^{z}\end{array}$ \\
\hline Interested in growing plants & 45.3 \\
\hline Needed a one-credit course & 41 \\
\hline Friend taking the class & 7.4 \\
\hline Heard the class was an easy $\mathrm{A}$ & 6.3 \\
\hline
\end{tabular}


Table 5. Students participating in ORH 1030-Plants, Gardens, and You and their overall satisfaction with the course $(\mathrm{N}=$ 95; mean = 4.40); 1 = lowest, 5 = highest.

\begin{tabular}{lc}
$\begin{array}{l}\text { Course } \\
\text { satisfaction }\end{array}$ & $\begin{array}{c}\text { Proportion of } \\
\text { students }(\%)^{\mathbf{z}}\end{array}$ \\
\hline 1 & 0.0 \\
2 & 2.0 \\
3 & 7.1 \\
4 & 38.8 \\
5 & 51.8 \\
\hline${ }^{2}$ Valid percent reported (rounding may yield totals \\
$<100 \%$ ).
\end{tabular}

$52 \%$ of the respondents rated the class as a 5 (Table 5 ), with the mean response of 4.40 .

Surveying students can prove to be a valuable tool. Determining more information about our students helps us better market the class and has proven very worthwhile. When the survey information was shared with the presenting faculty in ORH 1030, they modified their lectures to emphasize cultural care and maintenance of plants grown by most home owners and distributed handouts that would serve as references long after the students had graduated.

Course Wrap-up. Upon completion of the course, guest lecturers meet and review what worked and what did not. Suggestions are then implemented to aid in course improvement. Changes vary from more efficient ways to distribute class handouts to modifications of in class hands-on activities. Any department interested in teaching a survey class should include the wrapup. The input and comments will only help strengthen the class.

At UF the survey course ORH 1030-Plants, Gardens, and You has proven to be a welcome addition to our departmental curriculum. In addition to the student credit hours that the department gains, we are averaging 1 to 2 new students each semester who decide to pursue horticulture as a major and 3 to 4 students who decide to minor in horticulture. Most of these students were not aware of career opportunities in environmental horticul- ture before they enrolled in ORH 1030. As a recruiting tool, an undergraduate course such as this one can serve as an important, and timely method for introducing students to horticulture.

\section{Literature cited}

Barrett, J.E. 2000. Floriculture's recruiting woes: who should shoulder the blame? Greenhouse Product News 10(1):22-23.

Dalmasso, J.P. 1990. Reversing the trend of declining enrollments. Natl. Assn. Colleges Teachers Agr. J. 34:44-46.

Donnermeyer, J.F., and G.M. Kerps. 1994. Assessing college of agriculture freshmen. Natl. Assn. Colleges Teachers Agr. J. 34:44.

Dyer, J.E., L.M. Breja. and R.J. Anderson. 1999. Attitudes of college of agriculture freshman toward agriculture. J. Agr. Educ. 40(2):1-10.

Handelsman, J. 1992. Changing the image of agriculture through curriculum innovation, p. 199-203. In: M.K. Hayes (ed.). Agriculture and the undergraduate. Board Agr. Natl. Res. Council, Natl. Acad. Press, Washington D.C.

Kesler, D.J. 2000. Embracing and teaching nonmajors, as well as majors, in an animal science course, biology of reproduction. Natl. Assn. Colleges Teachers Agr. J. 40(3):11-20.

Kesler, D.J. 1997a. Introducing undergraduate students to animal science: A discovery course for nonmajors. J. Animal Sci. 75(1):273-276.

Kesler, D.J. 1997b. Teaching an animal science discovery course to freshman. Natl. Assn. Colleges Teachers Agr. J. 37(1):4247.

Likert, R. 1967. The method of constructing an attitude scale, p. 90-95. In: M.Fishbein (ed.). Readings in attitude theory and measurement. John Wiley and Sons, New York.

McConnell, D. B. 2000. Personal communication. Environ. Hort. Dept., Univ. Florida.

Terry, Jr., R. and D.E. Lawver. 1995. University students' perceptions of issues related to agriculture. J. Agr. Educ. 36(4):64-71.

University of Florida. 2000. Enrollment data. University of Florida, Gainesville. 